\title{
The Effects of Education and Parents' Income on Interest in Continuing Strata-2 / S2 Santri in Islamic Boarding School Students Jagad 'Alimussirry Institutions
}

\author{
M Nur Faritz ${ }^{1}$, R Rahmatika ${ }^{2}$ \\ ${ }^{1}$ Islamic Building School of Jagad Alimussirry Surabaya, Indonesia \\ ${ }^{2}$ Science Department, Universitas Negeri Surabaya \\ Email: miftaqhfaritz@gmail.com
}

\begin{abstract}
This research aims to analyze the role of parental education and parental income in influencing the interest in continuing S2 students in Islamic boarding school Students Jagad Alimussirry. This type of research is associative quantitative research. The subjects of this study were students of Islamic boarding school Jagad Alimussirry force 2016-2017 who are currently studying S1 at State University of Surabaya amounting to 32 students. Data collection techniques using instruments in the form of a questionnaire. Data from this research are in the form of the results of the students' responses to the questionnaire which were analyzed using the normality test, linearity test, multicollinearity test, autocorrelation test and heterokesdasticity test for the prerequisite tests of analysis. As for the hypothesis test using the $t$ test, $f$ test, and the coefficient of determination test. From this research it was found that (i) The majority of santri parents 'education was in the junior high school level by $34.37 \%$ (ii) The majority of santri parents' income was in the medium position of $62,5 \%$. (iii) $F$ Test results show that the independent variables (X1 and X2) are greater than the error level of 5\%. Based on the results of the study it can be concluded that the education and income of parents do not significantly influence the interest in continuing the study of S2 students in Islamic boarding school students Jagad Alimussirry.
\end{abstract}

Keywords: parental education; parental income; interest in continuing

\section{INTRODUCTION}

Education has an important role in bringing positive change in the development of a nation, education is one of the main instruments in developing the ability or potential of the next generation of a nation to become quality human resources, to achieve these goals a series of efforts that have been carried out by the government One of them is the development of higher education institutions, namely state and private tertiary institutions. Higher education is a level of education after secondary education that includes diploma, bachelor, master, specialist and doctoral education programs organized by tertiary institutions. Considering the important role of education in tertiary institutions, the interest of students to continue to a higher level or Masters needs to be developed and developed in students from the beginning. Interest directs deeds to an objective and is an encouragement for that action, interest can be a source of motivation that encourages people to do something in accordance with their desires, student interest in continuing their studies to a higher level or S2 program can be seen from the attitude of students who begin to put and focus attention on a matter that 
becomes a desire that is realized by efforts to dig up information about college he wants [1].

The following is preren data of the education variables of parents of students of the universe Alimussirry 2016 and 2017 as many as 17 respondents. It can be seen from 17 respondents obtained data on average education of santri parents, as many as 5 students whose parents 'education was only up to elementary / elementary school level, 3.5 students whose parents' education only reached junior high / junior high school level, and 5, 5 students whose parents 'education only graduated from senior high school, and 3 students whose parents' education up to 1 / S1 (Bachelor's) level of education, from the above provisional data prove that the education of santri's parents has different levels.

In addition to parental education, another factor influencing S2 study interest is parental income. Parents with good economic background or income can support the education of their children and can meet their learning needs. The influence between the economic level of the family and children's interest in continuing education is a high willingness to continue to Higher Education so that they tend to make efforts so that their desires are achieved [2]. Parents who have high incomes can meet the educational needs of their children, this is different from the economic background conditions or low income of parents, so they tend to try to fulfill their daily lives rather than their children's education. This is because the cost of continuing to college is not small, where the costs incurred for the cost of education in tertiary institutions which from year to year increase often makes parents less able to provide the cost of study.

The following is pre research data of income variables for parents of santri universe alimussirry for the 2016 and 2017 batch of 17 respondents. It can be seen that as many as 17 respondents obtained data on the average income of parents of students, as many as 7.5 students whose parents' income is below $\mathrm{Rp}$ 999,999, 5 students whose parents' income is around $\mathrm{Rp}$ 1,000,000-2,999,999, 1.5 students whose parents' income around Rp. 3,000,000 4,999,999 and 1 student whose parents 'income is above Rp. 5,000,000, from the above preliminary data it is known that the majority of santri's parents' income tends to be small and not up to 3 million for father and mother's income.

Santri Islamic Boarding School Students Jagad Alimussirry is often faced with various choices after completing their studies. Among these choices is the desire or interest to continue their education to a higher level, namely S2. However, several things are often considered by $\mathrm{S} 1$ graduates, including the educational background of their parents who are classified as low only at the junior high level, making the students and parents feel quite satisfied if they have completed tertiary education up to the $\mathrm{S} 1$ level. On the other hand the economic condition of parents is also a factor that is often considered by students of S1 to continue their studies to the S2 level. Given the costs that must be spent for the master's level is not exactly cheap, apart from the existence of various kinds of scholarships offered by many parties.

\section{METHOD}

This type of research is quantitative research because the data obtained will be realized in the form of numbers and analyzed based on statistics. This research is associative in nature which aims to determine the effect of one or two independent variables on the dependent variable, where this study seeks to influence the independent variable of parents 'educational background and parents' income on the dependent variable of interest in continuing their studies to the Masters level.

This research was conducted at the Islamic Boarding School Jagad Alimussirry Surabaya. The time of the study was carried out in March 2020. The population in this study were female students and non-formal undergraduate 
students of the 2016-2017 class of Student Jagad Alimussirry Surabaya. Which amounted to 42 students. The sample that can be taken in this study is the class of 2016-2017 who is studying S1 at Surabaya State University with a total sample of 32 students.

Data collection techniques used in this study were using a questionnaire. In this study, using a questionnaire or a closed questionnaire that is a questionnaire whose answers have been provided by researchers so that respondents simply choose. The questionnaire in this study consisted of questions that were distributed to respondents and used to collect data relating to education variables and parents' income and Interest in Continuing S2 to Higher Education.

\section{RESULT AND DISCUSSION}

\section{A. Interest in Continuing S2 Studies}

The variable data on Interest in Continuing to Higher Education is obtained through a questionnaire consisting of 14 question items with a number of respondents 30 . There are four alternative answers where the highest score is 4 and the lowest score is 1 . Based on the data analysis of the variable Interest in Continuing to Higher Education, the highest score can be obtained 53 and the lowest score is 37 , with a Mean value of 46.9 , Median of 47, Mode of 52, and Standard Deviation of 5,036. Furthermore Interest variables are classified into 4 categories of variable tendencies that are very high, high, medium and low. what is meant by the very high category is having a score of more than 50 , the high category has a score of between 46.5- 50, the medium category has a score between 43.5- 46.5, the low category has a score of less than 43.5, the score is obtained from the sum questionnaire score, and obtained criteria for tendency of interest in continuing S2 studies as follows:

Table I. Tendency of Interest

\begin{tabular}{|c|l|c|c|c|}
\hline \multirow{2}{*}{ No } & \multirow{2}{*}{ Score } & \multicolumn{2}{|c|}{ Frequency } & \multirow{2}{*}{ Categori } \\
\cline { 3 - 4 } & & Absolute & Relatively & \\
\hline 1 & $\mathrm{X}>50$ & 11 & $34,37 \%$ & Very high \\
\hline 2 & $46,5-50$ & 7 & $21,87 \%$ & High \\
\hline 3 & $43,5-46,5$ & 4 & $12,5 \%$ & Medium \\
\hline 4 & $X<43,5$ & 10 & $31,25 \%$ & Low \\
\hline & Total & 32 & $100 \%$ & \\
\hline
\end{tabular}

The table shows that there is a very high category of $11(34.7 \%)$, a high category of 7 $(21.87 \%)$, a medium category of $4(12.5 \%)$, and a low category of $10(31.25 \%)$. Thus it can be concluded that the variable of interest is included in the very high category of 11 (34.37\%).

\section{B. Parental Education}

Based on parental education data obtained through questionnaires in the form of average data from the highest level of education that has been taken by the father or mother, then scoring according to the level of parental education. The results of the analysis and research show that for the variable of parental education, the highest score of 4 and the lowest score of 1 . The parent variables of education can be classified into elementary, junior high, senior high and undergraduate categories. The categorization is as follows:

Tabel 2. Category of Parental Education

\begin{tabular}{|c|c|c|c|c|}
\hline No & Category & Frequency & $\%$ & Category \\
\hline 1 & 1 & 6 & $18,75 \%$ & Elementary \\
\hline 2 & 2 & 11 & $34,37 \%$ & Junior High \\
\hline 3 & 3 & 7 & $21,87 \%$ & Senior High \\
\hline 4 & 4 & 8 & $25 \%$ & Undergraduate \\
\hline & Total & 32 & $100 \%$ & \\
\hline
\end{tabular}

The table shows that there are elementary school graduates by $6(18.75 \%)$, junior high school graduates by $11(34.37 \%)$, senior high school graduates by 7 (21.87\%), and undergraduate graduates by $8(25 \%)$. Thus it can be concluded that the Parent Education variable is included in the category of junior high school graduates by $34.37 \%$.

\section{Parental Income}

Variable data of parental income obtained through questionnaires in the form of father and mother income per month which is categorized into 4 types with different income ranges, income of father and mother added to one as the income of each respondent's parents amounting to 32 students.

Furthermore, the Parent Income variable is classified into 4 categories according to the 
Central Statistics Agency in 2008, namely very high income, high income, medium income, and low income. The categorization made by researchers in the Parent Income variable is based on 4 categories with the following

Table 3. Category of Parental Income

\begin{tabular}{|c|c|c|}
\hline No & Interval & Category \\
\hline 1 & 2 Rp5.000.000 & Vey High \\
\hline 2 & Rp3.000.000-Rp4.999.999 & High \\
\hline 3 & Rp1.000.000-Rp2.999.999 & Medium \\
\hline 4 & $\leq$ Rp999.999 & Low \\
\hline
\end{tabular}

Based on these calculations, the criteria for parental income trends are obtained as follows.

Table 4. Criteria tendency of Parental Income

\begin{tabular}{|c|c|c|c|c|}
\hline No & Interval & $\mathrm{F}$ & $\%$ & Category \\
\hline 1 & $2 \mathrm{Rp} 5.000 .000$ & 0 & $0 \%$ & Very High \\
\hline 2 & $\mathrm{Rp} 3.000 .000-\mathrm{Rp} 4.999 .999$ & 4 & $12,5 \%$ & High \\
\hline 3 & $\mathrm{Rp} 1.000 .000-\mathrm{Rp} 2.999 .999$ & 20 & $62,5 \%$ & Medium \\
\hline 4 & $\leq \mathrm{Rp} 999.999$ & 8 & $25 \%$ & Low \\
\hline & Total & 32 & $100 \%$ & \\
\hline
\end{tabular}

The table shows that there is a very high income category of $0(0 \%)$, a high income category of $4(12.5 \%)$, a medium income category of $20(63.5 \%)$, and a low income category of $8(25 \%)$. Thus it can be concluded that the Parent Income variable is included in the medium income category of $62.5 \%$.

Based on the Research Data it is known that the majority of santri parents' education is in junior high school with a percentage of $34.37 \%$ of the total sample taken, the income of santri parents is in the medium position of $62.5 \%$ of the total sample taken ie with a range of income of Rp 1,000,000-2,999,999, with a tendency to be very interested in continuing S2 studies at $34.37 \%$, the results of the $\mathrm{F}$ Test showed that the F count was 0.816450 with a probability level of $0.451901>0.05$, above the error level of $5 \%$, this means that the independent variable (education and income) does not significantly influence the dependent variable (interest).

The results of this study are the same as research conducted by (Winahyu, 2009) which proves that there is no influence between parental education, parental income and learning achievement on children's interest in continuing education to college [3] and the results of this study reject / contradicting the statement (Halimah, Mahmu'ddin, \& Purwanti, 2018), in the STKIP journals of education in Muhammadiyah Sampit which in their research proved that simultaneously there was an influence of the level of education and income of parents on the interest in continuing education to college [4]. According to the researchers 'view that the interest in continuing S2 studies at students' boarding students is formed and influenced by the social environment of Islamic boarding schools, especially from directors, administrators, religious teachers and experienced senior students, as well as open access to information on scholarships and independence of students in earning additional income so that the interest here is not influenced by the education and income of his parents.

The results of the coefficient of determination show the EVIEWS random effect model output known adjusted $\mathrm{R}$ square (R2) -0.011984 . This shows that $1.2 \%$ of interest in continuing S2 studies can be explained through a variety of independent variables namely education and income, while $98.8 \%$ is explained by other variables outside the model.

According to the views of religion and researchers the interest of children to succeed in education and science cannot be separated from two important factors, namely teachers and parents. Like a great cleric in the class of Imam Syafi'i and Izzuddin bin Abdis Salam became a great scholar with the title Sulthanul Ulama (ulama leader), because he highly respected the teacher. Namely, by way of structuring two slippers every time you teach. 
In fact he added, he was an orphan and a poor person. By Allah's permission, because he respected the teacher and put his knowledge into practice, he became a great man. Added, Imam Syafi'i became a great person not only because of his great knowledge, but also because he was very obedient and respectful to his teacher, so he was given glory beyond his teacher, and obedient Imam Syafi'i at the behest of the mother

Imam Syafi'I was told as a child when he was visited by a group of robbers who would seize the assets of those who were on the way, including a Imam Syafi' $i$, a small $i$, one of the robbers came to Syafi'i, I was small and asked if you were hiding possessions? No and he gave the treasure he had, then the little Syafi'i was asked by the robber why didn't you hide it? No, my mother advised me not to lie to my mother on the way. And for the blessings of Imam Syafi'i's mother who allowed him to study at a faraway land. If you want to be successful and big people don't just rely on science. But, also never forget to do good to those who have contributed to and do good to us, namely parents and teachers (Kyai Abdul Basid Mansur).

The role of the teacher as a motivator is very important in order to increase the enthusiasm and development of student learning activities. Teachers must be able to stimulate and provide encouragement and reinforcement to dynamize students' potential, foster self-help (activity) and creativity (creativity), so that there is a dynamic in the teaching and learning process. According to Dimyati and Mudjiono (2009) parental motivation is seen as a mental drive that drives and directs human behavior including learning behavior. [5] From the brief explanation above it is known that parents and teachers play an important role in motivating children in learning / studying.

\section{CONCLUSION}

Based on the description above, it can be concluded that the education and income of parents do not significantly influence the interest in continuing the study of S2 students of Jagad Alimussirry. In the view of researchers the biggest factor in determining interest in continuing S2 studies is due to good environmental factors. Inside students of Jagad Alimussirry information about S2 level scholarships is very easy to obtain given there is a forum consisting of students who continue their S2 and S3 studies with scholarships. The students also have a lot of relationships regarding a job and career path so that in their free time they have side jobs, thus indirectly reducing children's dependence on their parents in the cost / financial aspect. The results of this study support research conducted by (Dyah, 2018), (Sari, 2015) that parental education and parental income do not affect study interest in higher education. This research is contrary to the results of research conducted by (Budisantoso, 2016), (Rini, 2012), (Sumakta, 2015), (Azizah, 2019), (Halimah, Mahmu'ddin, \& Purwanti, 2018). That parental education and parental income significantly influence study interest in higher education

\section{REFERENCES}

[1] Ngalim Purwanto (2006). Psikologi Pendidikan. Bandung : PT Remaja Rosda Karya

[2] Salmah. (2013). Pengaruh Status Sosial Ekonomi Keluarga Terhadap Motivasi Melanjutkan Ke Perguruan Tinggi Di Mas Pontianak. Jurnal Pendidikan dan Pembelajaran 2(9), 1-13.

[3] Winahyu, P. D. (2009). Hubungan Antara Tingkat Pendidikan Orang Tua dan Pendapatan Orang Tua dan Prestasi belajar, Siswa Dengan Minat melanjutkan Stidi Ke Sekolah Menengah Kejuruan (SMK)

[4] Halimah, S., Mahmu'ddin, \& Purwanti, s. (2018). Tingkat Pendidikan Orang Tua dan Pendapatan Orang Tua Terhadap Minat Melanjutkan Studi Ke Perguruan Tinggi. 
Jurnal Pedagogie STKIP Muhammadiyah Sampit,

[5] Vol. VI, No.1, Januari-Juni

[6] Dimyati, Mudijono. (2009) Belajar dan Pembelajaran. Jakarta: PT. Rineka Cipta. 